\title{
Role of Social and Educational Factors on the Educational Development of literates
}

\author{
Vida, Rahiminezhad ${ }^{1}$ \\ ${ }^{1}$ Organization for Educational Research and Planning, Research Institute for Education, Iran, A Board Member \\ of Iranian Association for Sociology
}

\begin{abstract}
Different factors have important role on the educational development of those literates who first attended in literacy classes of Literacy Organization in Iran to learn how to read and write and later on achieved academic education. Social and educational factors are among the most important ones. The aim of this article is to study of the role of social and educational factors on the educational development of these successful literates. Social factors include the location of literates, being members of any rural or urban council, and any other associations. Educational factors include content of textbooks, teaching methods, and the classmates' effect. This is a quantitative study. The population is all those literates who achieved academic degree, but first they had registered in the classes of Literacy Organization in Iran in order to learn how to read and write. Sample size consists of 666 successful literates across the country. Instrument is a research made questionnaire. The results show that the location of successful literates at the time of registration in literacy classes does not have any relations to their educational development, but being member of any councils or organizations was relevant to their educational development, since 29.41 percent of these successful literates were members of different councils or associations. 65 percent of successful literates confirmed that the teaching method of teachers in literacy classes had important role in their development.
\end{abstract}

Keywords: literacy, educational development, social factors, textbooks, teaching method

\section{Introduction}

High education is one of the most important factors in sustainable. Developed countries generally focused in high education as one of the basic factors on achieving sustainable. The impact of education and especially high education such that cause the emergence of every day differences innovation in developed societies [8]. This article investigates the effective factors on the educational development of those illiterate adults who attend in literacy classes of literacy organization and achieved high education or pass entrance exam of universities. Among different factors impact on education social and educational factors are taken into consideration in this article.

Coleman emphasized the role of social capital out of family on the educational success of students. He noted about the social organization such as schools, public institutes and so on. As Sadeqi [4] noted, Gronter believed that strong relation between member of families and relatives is an important factor on educational behavior but this relation could not provide the variety of non-relative relations and the amount of information one gets through such relations [4].

The other factor which is considered as social variable is the role of friends in schools and their places, since friends could impact the attitude and educational behavior of each other [5]. The educational success of students in accessing academic education not only related to the individual and family attempt but also educational factors in schools which are the educational and sport facilities, teachers, and educational environment in schools [2]. Seif [7] noted that class structure textbooks and their contents, teacher's experience, and the cooperation of students in teaching process are among those of educational factors. One of the most important educational factors is teachers. In considering teacher's impact, the teaching method, experience of teachers, scientific background should be considered.

Hosseini [3] in educational year of 1983-1984 studied on the characteristics of those who accepted in Shiraz University in 1976-1977. He reached to the point that there is relation between the location of education and their location before accepting in university and understood that those who located in Shiraz and capital are more successful than others. In other studies Hosseini [3] compared 3872 of successful and unsuccessful students and 
find that the average of successful students during high school are higher than unsuccessful students and those students who belong to average classes are more successful than those who belong to low classes.

This is a survey research. Population includes all those successful literates who attended in literacy classes and then either completed their high education, and achieved university degree or at the moment study in any universities in Iran. There are 1314 successful literates in Iran according to database provided in 2005. Sample size equals to the whole population and research instrument is research made questionnaire. Questionnaire includes 27 items include choices of two to seven. Content validity of questionnaire is confirmed by scholars and reliability of items is assessed by the use of Cronbach test which was 75 percent. In descriptive analysis frequency and mean and for inferential statistics chi square test and Spearman correlation coefficient are used. The total number of participants in this research includes 666.

\section{Operational Definitions}

\subsection{Successful literates}

Successful literates are those who attended in literacy classes of literacy organization in Iran and at the moment are students in different universities or achieved university degrees

\subsection{Universities}

All those colleges and universities which provide university degree which include different colleges, Payame Noor University, University of Applied Science, public universities [6].

\subsection{Social factors}

Social factors in this study include the location where the literates attend in literacy classes for the first time either in urban or rural areas and being member of any councils or associations.

\subsection{Educational factors}

These factors are contents of textbooks, methodology and behavior of teachers and classmates of literates at the time of attending in literacy classes.

\section{Participants}

Questionnaire is sent to all provinces and just 666 are completed. The distribution of questionnaire is shown in table no. 1.

TABLE I: Distribution of participants in this study in 2015

\begin{tabular}{|c|c|c|}
\hline Province & Frequency & Parentage \\
\hline Kermanshah & 102 & $15 / 3$ \\
\hline Ardebil & 89 & $13 / 4$ \\
\hline $\begin{array}{c}\text { East } \\
\text { Azarbayejan }\end{array}$ & 85 & $12 / 8$ \\
\hline Zanjan & 74 & $11 / 1$ \\
\hline Lorestan & 60 & $9 / 0$ \\
\hline Mazandaran & 56 & $8 / 4$ \\
\hline $\begin{array}{l}\text { Kohgiloye and } \\
\text { Boyer Ahmad }\end{array}$ & 38 & $5 / 7$ \\
\hline Fars & 36 & $5 / 4$ \\
\hline Kordestan & 29 & $4 / 4$ \\
\hline $\begin{array}{c}\text { Khorasan } \\
\text { Razavi }\end{array}$ & 26 & $4 / 0$ \\
\hline Qom & 24 & $3 / 6$ \\
\hline $\begin{array}{c}\text { Charmahal e } \\
\text { Bakhtiyari }\end{array}$ & 20 & $3 / 0$ \\
\hline Esfahan & 6 & $0 / 9$ \\
\hline Markazi & 6 & $0 / 9$ \\
\hline $\begin{array}{c}\text { Sistan and } \\
\text { Balochestan }\end{array}$ & 5 & $0 / 8$ \\
\hline Gilan & 4 & $15 / 3$ \\
\hline Kerman & 3 & $13 / 4$ \\
\hline Boshehr & 2 & $12 / 8$ \\
\hline Qazvin & 1 & $11 / 1$ \\
\hline Sum & 666 & $9 / 0$ \\
\hline
\end{tabular}


Based on table no. 1 Kermanshah province with the number of 102 participants has got first position and central and Isfahan provinces with 6 participants in each both have got the last position in this table.

\subsection{Distribution of participant based on their location}

One of the questionnaires's item asking about the location of literates at the time attending in literacy classes. The following table shows the distribution of participants based on their location.

TABLE II: Distribution of participants based on their locations

\begin{tabular}{ccc}
\hline Location & Frequency & Percentage \\
\hline urban & 457 & $68 / 6$ \\
Rural & 207 & $31 / 1$ \\
No answers & 2 & $0 / 3$ \\
Sum & 666 & 100 \\
\hline
\end{tabular}

Based on data in table no. 2 about 68.6 percent of participants lived in cities at the time of attending in literacy classes and 31.1 percent lived in urban areas and 0.3 percent did not answer the question.

\section{Findings}

Variables investigate as social factors as it is already said includes the location and being member of any council or association in urban or rural areas. Data shows that 58.6 percent of successful literates lived in urban and 31.1 percent lived in rural areas. About 2.4 percent of participants did not answer where they lived at the time of attending in literacy classes. In order to examine the relation between successful literates and their location Chi-square test is used. The amount of this test equals to 1.910 with freedom degree of 3 which means there are not any significant relation between their location and educational development of literates.

From total number of 666 participants 632 (94.9 percent) answer the question that whether they were the member of any councils or associations, which 144 women out of 533 women (27.06 percent) declared that they were member of one of the councils and associations, while 25 men ( 25.25 percent) from the total number of 99 admitted that they had gotten the membership of one council. The percentage of successful literates who were a member of any council includes 25.98 percent of associate degree, 25.38 percent of bachelor degree, and 29.41 percent of Master or $\mathrm{PhD}$. degree. As it is shown the highest frequency belong to those who had master or $\mathrm{PhD}$. degree.

The relation between education development and being member of any council is investigated through Chisquare. The amount of Chi-square equals to 15.396 with freedom degree of 6 which is significant in less level of 0.05. It means that there is a relationship between educational development of literates and their membership in any council or associations.

Variables of educational factors which have taken into consideration are teaching method and behavior of teachers, contents of textbooks, and classmates at the time of attending in literacy classes. Data shows that 68.5 percent of participants are in belief that teaching method and behavior of teachers are the most important factors in their educational development, and then the contents of the text books with 16.8 percent and the last position belongs to the classmates with 9.6 percent.

\section{Conclusion}

The aim of this article is to investigate over the relation between social and educational factors with the educational development of those adult literate who first attended in literacy classes of Literacy Organization in Iran and later could achieve university degrees. The methodology of this research is survey. The instrument is research made questionnaire. Among 1314 successful literate based on database in 2005 [1] just 666 persons participated in this study. The study shows that the location of successful literate at the time of registering in literacy classes does not have any relation with their developmental education, but there is relation between 
being member of councils and associations and their developmental education, since 29.41 percent of successful literate could achieve to Master and doctoral degree. Hosseini [3] in his research understood that those who lived in Shiraz city or in capital could achieve educational success more than those who lived in rural areas. But as it is said this research could not find any relation between the location and educational development of successful literates.

Among those educational factors during literacy period, 68.5 percent of successful literate declares that it is the method of teaching and the behavior of teachers who put effect on their educational development, which has got the first position among other factors which are contents of textbooks and the impact of classmates.

\section{References}

[1] Database of successful literate in Iran. Literacy Organization in Iran. 2005.

[2] Dehqan, Hossein. A Study of Relation between Economic-social Position and the Educational Operation. M.S. thesis. Beheshti University. 2004.

[3] Hosseini, Ali Akbar. A Study of some characteristics of those who accepted in Shiraz University in 1983- 1984. Journal of Humanities and sociology of Shiraz University, no. 2. 1987.

[4] Sadeqi, Narges. A Study of Effective Factors on the Success and Failure of Volunteers with Diploma Average Above 29 in Entrance Exam in 1998. Master Thesis, Azahra University, Social and Economic College. 1998.

[5] Saee, Rahim. A Study of Effective Factors on the Educational Development of Students in Agriculture Department. M.A. thesis. 1998.

[6] Safi, Ahmad. Educational Guide in Universities and High Education Centers in Iran. Tehran: Ravan publication house. 2004.

[7] Seif, Ali Akbar. Measuring, Assesment, and Educaitonal Evaluation, Tehran: Nashr Doran. 2009.

[8] Mahajer, Alireza. Individual and Educational Factors on the educational Development. M.S. thesis. Psychology and Education College, Tehran University. 2006. 